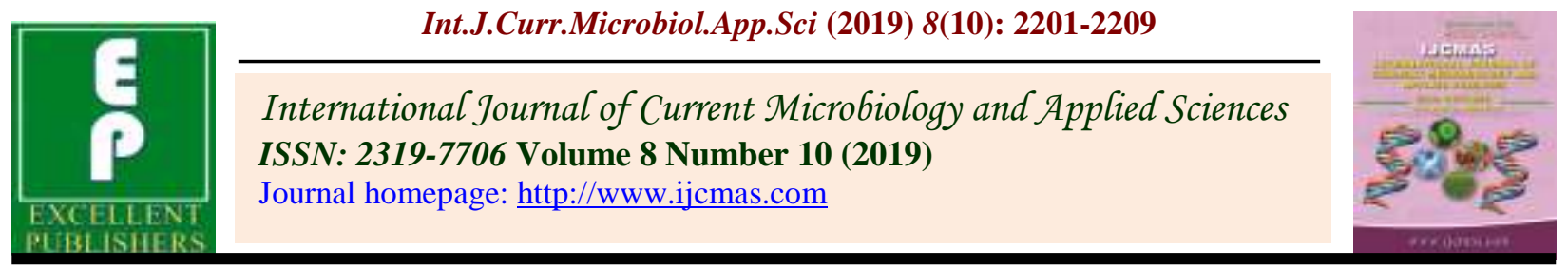

Original Research Article

https://doi.org/10.20546/ijcmas.2019.810.256

\title{
Genetic Variability in Custard Apple Landraces of Madhya Pradesh, India
}

\author{
Kamleshwar Goutam*, T. R. Sharma, B. K. Verma, U. K. Chanderia and S. K. Pandey \\ Department of Horticulture, College of Agriculture, JNKVV, Jabalpur- 482004 (MP), India
}

*Corresponding author

\section{A B S T R A C T}

\section{Keywords}

Custard apple,

Genotype,

Qualitative,

Quantitative

Article Info

Accepted:

15 September 2019

Available Online:

10 October 2019
The present investigation entitled "Diversity in Custard apple genotypes collections from Madhya Pradesh, India" was carried out during 2018-2019 at Fruit Preservation Laboratory, Department of Horticulture, College of Agriculture, Jawaharlal Nehru Krishi Vishwa Vidyalaya, Jabalpur (M.P.). The experimental material for the present investigation was comprised of twenty genotypes of custard apple collected from four districts of Madhya Pradesh.Among 20 promising genotype significantly maximum length of fruit $(90.55 \mathrm{~mm})$, width of fruit $(91.49 \mathrm{~mm})$, weight of fruit $(287.77 \mathrm{~g})$, fruit pulp per cent $(71.25 \%)$ and non reducing sugar per cent $(8.60 \%)$ was observed in genotypes SEO-04 and it was recorded minimum number of seeds fruit ${ }^{-1}$ (16.95), weight of seeds fruit ${ }^{-1}$ (5.98 g) and peel weight fruit ${ }^{-1}(42.13 \mathrm{~g})$. Genotype DRH 04 exhibited maximum volume of fruit $(266.65 \mathrm{cc})$. TSS $(30.49)$, acidity per cent $(0.22 \%)$ and TSS: acidity ratio (141.67) was registered maximum in CHH -03 . Genotype DHR -05 was noted maximum total sugar per cent $(24.08 \%)$ and reducing sugar per cent $(18.15 \%)$.

\section{Introduction}

Custard apple (Annona squamosa L.), belongs to a family "Annonaceae", and also known as Sitaphal or Sharifa. It is an important dryland fruit of India.It belongs to tropical climate and native of tropical America and surrounding regions. Annona means year's harvest (Lizana and Reginato, 1990) and Speciessquamosa means scaly, referring to the scale like structure of the fruit surface. Some botanists have considered it to be a native fruit of that country. In India, it is presently grown on44000 ha area covering the states of Maharashtra, Gujarat, Madhya Pradesh, Andhra Pradesh, Telangana, Chhattisgarh, Karnataka, Bihar, Odisha, Assam and Tamil Nadu with the production of 367 MT (Anonymous, 2017). In MP, cultivated area is 3,590 ha with production 37.00 MT (Anonymous, 2015). Custard apple having high nutrient and medicinal value with short 
span of availability of fruits. It is considered as beneficial for cardiac diseases, diabetes, hyperthyroidism, cancer etc. It is rich in carbohydrate $(23.5 \mathrm{~g})$, protein $(16.6 \mathrm{~g})$, mineral $(0.9 \mathrm{~g})$, fiber $(3.1 \mathrm{~g})$, calcium $(17 \mathrm{mg})$, phosphorus (47 mg), iron (1.5 g) and VitaminC (37 mg), in a 100 gram fruit pulp (Gopalan et al., 1997). This fruits are generally used as fresh and custard powder are prepared either mixed with other fruits or alone. It is also used for preparing ICE cream.

Custard apple is gaining commercial significance now a day and several commercial orchards are immerging in Andhra Pradesh and Maharashtra (Yadav et al., 2017). A rich diversity of custard apple exist in Madhya Pradesh andmajor growing districts are Chhindwara, Seoni, Betul, Raisen, Sagar, Dhar, Khandwa, Khargone, Jhabua, Dindori, Sehore, Mandla and Harda (Nair and Agrawal, 2017).

It shows that wide adoptability under different location and climatic conditions. Thus, there is immense scope of genetic improvement of custard apple through selection of promising genotype from wild genetic diversity rich regions of M.P. Keeping the above points in view an extensive survey was carried out to collect superior germplasm from Kymore plateau and Satpurahills, climatic zone of Madhya Pradesh in order to evaluate them for their quantitative and qualitative traits.

\section{Materials and Methods}

A Survey and characterization study entitled "Genetic Variability in land races of custard apple of Madhya Pradesh, India"was carried out during 2018-2019. The collected land races were characterized with respect to qualitative and quantitative traits in the fruit laboratory, Department of Horticulture, JNKVV Jabalpur (M.P.). The study consisted of landraces of custard apple fromthree agro climatic zones of Madhya Pradesh. Collection belongs to Kymore plateau and Satpura hills, Satpura plateau and Malwa plateau. These land races were distinguished based on plant type, (Tall, Semi Tall and Dwarf), plant canopy (Spreading semi spreading and upright), and size (Length, width, weight and volume) as well as shape (cordate broadly cordate, and round) of fruits. These collected data were statistically analyzed under Complete Randomized Design (C.R.D.) considering the three locations as replication. The survey of predominant growing areas was done during the rabi 2018. Twenty diverse landraces of custard apple were collected from each agro climatic zone Taken under study. Observations were recorded on the basis of randomly selected three competitive plants with respect to type, canopy, fruit shape and size of each landrace, separately, for studding the morphological, physical and chemical traits. The evaluation was done by following the standard procedure. Data pertaining to fruits quantitate (number of seeds fruit $^{-1}$, Weight of seeds fruit ${ }^{-1}(\mathrm{~g})$, Fruit pulp $(\%)$, Peel weight fruit $^{-1}(\mathrm{~g})$, and qualitative traits (Total soluble solids ( ${ }^{0}$ Brix), Acidity (\%), TSS: Acid ratio as per given by AOAC, 1995 and total sugars (\%) (Ranganna, 1991) were recorded and subejected to statistical analysis.

\section{Results and Discussion}

The date is presented in Table 1 with respect to plant type, shape of canopy, fruit shape and fruit colour. The mean performance of the genotypes revealed a wide range of variability for all these traits. Among the 20 genotypes, plant types of landraces genotypes $\mathrm{CHH}-03$, JBP-03, SEO-01 and DHR-02 were having tall plant and remaining genotypes were exhibited semi tall nature. It indicates that the expression of plant characters was not uniform (Hazarika et al., 2013). 
The growth habit of different genotype was visually observed as upright and spreading.Upright shape of canopy was observed in genotype $\mathrm{CHH}-01$ and $\mathrm{CHH}-03$, JBP-03 and JBP-05, SEO-01, SEO-03 and DHR-02 which were collected from Chhindwara, Jabalpur, Seoni and Dhar, respectively, and remaining genotypes had spreading canopy. The fruits of different genotype also showed variations in their shape and colour. Genotypes CHH-01, CHH-02, CHH-03 collected from Chhindwara, JBP-04, from Jabalpur, SEO-03, SEO-04 and SEO-05 from Seoni and DHR-02 and DHR-05 from Dhar district of M.P. possessed cordate fruit shape. Whereas, genotypes JBP-02 collected from Jabalpur had broadly cordate fruit shape.Based on the fruit colour genotypes SEO-04 and SEO-05 from Seoni were recorded light brown colour. While, genotypes CHH-01 and CHH-05 from Chhindwara, JBP03 and JBP-04 from Jabalpur, SEO-01, SEO04 and SEO-05 from Seoni,DHR-02 and DHR-02 from Dhar district were exhibited light green fruit colour while remaining all the fruits genotypes were green.

The fruits of different genotypes varied considerably with respect to some quantitative traits viz., length of fruit, width of fruit, weight of fruit, volume of fruit, are presented in table 2. It is apparent from the data that the lowest fruit length $90.55 \mathrm{~mm}$ of genotype SEO-03 was noted which was at par with DHR-02 $(84.60 \mathrm{~mm})$ and DHR-04 $(83.66 \mathrm{~mm})$, while, minimum length of fruit $(51.80 \mathrm{~mm})$ was rescored under $\mathrm{CHH} 01$ and fruit width ranging from $59.01 \mathrm{~mm}$ to $91.49 \mathrm{~mm}$ and highest fruit width of $91.49 \mathrm{~mm}$ was recorded in SEO-03, followed by DHR-02(86.62mm) and DHR-01(86.32mm).

These findings are in agreement with that of Kolekar and Tagad (2012), Diwan et al., (2014) and $\mathrm{Kad}$ et al., (2016). The maximum fruit weight of $287.77 \mathrm{~g}$ was observed in SEO-
03 which registered its superiority over rest of the genotypes under study. While, minimum fruit weight of $99.99(\mathrm{~g})$ was recorded under $\mathrm{CHH}-01$. The variation in fruit weight is correlated with the variation in fruit length and width. These results are in conformity with those of Hashmi and Pawar (2012) and Raina et al., ( 2014). Fruit weight is genetically controlled character, hence significant variation was recorded in different land races (Bhatnagar et al., 2012). The volume of fruit ranged from $59.40 \mathrm{cc}$ to $266.65 \mathrm{cc}$, being wide range of variations in genotypes. The maximum $266.65 \mathrm{cc}$ and minimum $59.40 \mathrm{cc}$ fruit volume was recorded in genotypes DHR04 and $\mathrm{CHH}-01$ respectively.

As regards to the seed counts in fruits it was noted that the minimum number of seeds fruit $^{-1}$ (16.95) was observed in genotype SEO04 followed by SEO-1(19.39), DHR-03 (20.33), SEO-05 (23.01) and DHR-04(23.12), these genotype were at par with each other. However, maximum 60.41 was recorded in JBP-01. The genotypes with very less number of seeds could be utilized in the breeding programme for development of seedless varieties of custard apple. These results are similar to findings as reported by Yadav et.al, 2017 in custard apple collected from semi-arid reasons of Gujarat.

The minimum weight of seeds fruit ${ }^{-1}(16.95 \mathrm{~g})$ was noted under genotypes SEO-04and was at par with SEO-01, DHR-03 and SEO-05 with $19.39 \mathrm{~g}, 26.33 \mathrm{~g}$ and $23.01 \mathrm{~g}$ seed weight per fruit, respectively. While it was maximum $(53.48 \mathrm{~g})$ under the JBP-05. The findings are in agreement with the result of Bhatnagar et al., (2012). Regards to the fruit pulp per cent were noted for the genotype SEO-03(71.25\%) followed by DHR-02(70.23\%), DHR$03(69.02 \%)$. While, it was recorded minimum in the genotype $\mathrm{CHH}-01(23.32 \%)$. Higher percentage of pulp is considered as desirable traits in custard apple selection. High pulp \% 
verities are good for processing purpose. The minimum peel weight fruit $^{-1}(42.13 \mathrm{~g})$ was noted under the genotype SEO-04 which is at par with CHH-05(48.72g) and DHR$03(49.71 \mathrm{~g})$ while maximum $(70.87 \mathrm{~g})$ was observed in SEO-03 (Table 3).

\section{Quality of custard apple}

The qualitative parameters with respect to TSS, acidity \%, total sugar, reducing sugar, non-reducing sugar, and TSS: acidity ratio was analyzed and recorded data are presented in table 4. It is evident from the data that there were some significant variations among the land races were collected from different agro climatic zones of M.P.

Among the various zones Satpuraplatue consisted of Chhindwara and Seoni possessed the higher value of TSS in fruits ranging from 19.81 to 30.49 and 23.96 to $30.15^{0}$ Brix respectively, moreover Malva Plateau having the similar value of TSS ranging from 22.10 to $30.19{ }^{0}$ Brix.

Table.1 Morphological plant characteristics of various land races of custard apple

\begin{tabular}{|c|c|c|c|c|}
\hline Genotypes & Plant type & Canopy shape & Fruit shape & Fruit colour \\
\hline CHH-01 & Semi tall & Upright & Cordate & Light green \\
\hline CHH-02 & Semi tall & Spreading & Cordate & Green \\
\hline CHH-03 & Tall & Upright & Cordate & Green \\
\hline CHH-04 & Semi tall & Spreading & Round & Green \\
\hline CHH-05 & Semi tall & Spreading & Round & Light green \\
\hline JBP-01 & Semi tall & Spreading & Round & Green \\
\hline JBP-02 & Semi tall & Spreading & Broadly cordate & Green \\
\hline JBP-03 & Tall & Upright & Round & Light green \\
\hline JBP-04 & Semi tall & Spreading & Cordate & Light green \\
\hline JBP-05 & Semi tall & Upright & Round & Green \\
\hline SEO-01 & Tall & Upright & Round & Light green \\
\hline SEO-02 & Semi tall & Spreading & Round & Green \\
\hline SEO-03 & Semi tall & Upright & Cordate & Green \\
\hline SEO-04 & Semi tall & Semi Spreading & Cordate & Light brown \\
\hline SEO-05 & Semi tall & Semi Spreading & Cordate & Light brown \\
\hline DHR-01 & Semi tall & Spreading & Round & Green \\
\hline DHR-02 & Tall & Upright & Cordate & Light green \\
\hline DHR-03 & Semi tall & Spreading & Round & Light green \\
\hline DHR-04 & Semi tall & Upright & Round & Green \\
\hline DHR-05 & Semi tall & Spreading & Cordate & Green \\
\hline
\end{tabular}


Table.2 Fruit Size, Length, width ( $\mathrm{mm})$ weight $(\mathrm{g})$ and volume (cc), of various land races of custard apple

\begin{tabular}{|c|c|c|c|c|}
\hline Genotypes & $\begin{array}{c}\text { Length of fruit } \\
(\mathbf{m m})\end{array}$ & $\begin{array}{c}\text { Width of fruit } \\
(\mathbf{m m})\end{array}$ & $\begin{array}{c}\text { Weight of fruit } \\
\mathbf{( g )}\end{array}$ & $\begin{array}{c}\text { Volume of } \\
\text { fruit }(\mathbf{c c})\end{array}$ \\
\hline CHH-01 & 51.80 & 59.10 & 99.99 & 59.40 \\
\hline CHH-02 & 59.31 & 63.57 & 118.91 & 66.07 \\
\hline CHH-03 & 59.68 & 67.71 & 120.72 & 126.81 \\
\hline CHH-04 & 58.79 & 62.40 & 158.35 & 116.73 \\
\hline CHH-05 & 53.59 & 65.55 & 109.37 & 125.27 \\
\hline Mean & 56.63 & 63.67 & 121.47 & 98.86 \\
\hline JBP-01 & 66.20 & 70.49 & 179.25 & 153.50 \\
\hline JBP-02 & 70.03 & 77.47 & 226.67 & 192.17 \\
\hline JBP-03 & 61.60 & 70.59 & 199.43 & 184.66 \\
\hline JBP-04 & 70.28 & 71.39 & 204.40 & 177.96 \\
\hline JBP-05 & 71.56 & 61.31 & 264.35 & 237.11 \\
\hline Mean & 67.93 & 70.25 & 214.82 & 189.08 \\
\hline SEO-01 & 69.52 & 72.48 & 161.21 & 132.64 \\
\hline SEO-02 & 76.85 & 77.44 & 207.42 & 169.52 \\
\hline SEO-03 & 90.55 & 91.49 & 287.77 & 162.61 \\
\hline SEO-04 & 70.46 & 68.72 & 141.60 & 104.70 \\
\hline SEO-05 & 60.69 & 64.51 & 120.06 & 115.06 \\
\hline Mean & 73.61 & 74.93 & 183.61 & 136.91 \\
\hline DHR-01 & 78.31 & 86.32 & 191.70 & 210.77 \\
\hline DHR-02 & 84.60 & 86.62 & 253.78 & 218.24 \\
\hline DHR-03 & 79.81 & 76.38 & 183.96 & 198.19 \\
\hline DHR-04 & 83.66 & 83.61 & 219.36 & 266.65 \\
\hline DHR-05 & 72.40 & 72.57 & 148.25 & 153.43 \\
\hline S.Em \pm & 2.47 & 2.40 & 9.80 & 9.15 \\
\hline C.D-5\% & 7.06 & 6.85 & 28.00 & 26.16 \\
\hline level & & & & \\
\hline & & & & \\
\hline
\end{tabular}


Table.3 Characterization of fruit with respect to no. of seed, seed weight, peel weight per fruit and pulp percentage in different landraces

\begin{tabular}{|c|c|c|c|c|}
\hline Genotypes & $\begin{array}{c}\text { No. of } \\
\text { seedsfruit }^{-1}\end{array}$ & $\begin{array}{c}\text { Weight of } \\
\text { seeds fruit } \\
\text { (g) }\end{array}$ & Fruit pulp (\%) & $\begin{array}{c}\text { Peel weight fruit }^{-1} \\
\text { (g) }\end{array}$ \\
\hline CHH-01 & 55.44 & 12.87 & 23.32 & 63.66 \\
\hline CHH-02 & 52.85 & 13.21 & 38.04 & 59.93 \\
\hline CHH-03 & 50.73 & 12.68 & 38.48 & 60.87 \\
\hline CHH-04 & 56.84 & 13.70 & 48.41 & 67.99 \\
\hline CHH-05 & 57.67 & 14.42 & 42.27 & 48.72 \\
\hline Mean & 54.71 & 13.38 & 38.10 & 60.23 \\
\hline JBP-01 & 60.41 & 15.85 & 54.83 & 65.11 \\
\hline JBP-02 & 33.51 & 9.85 & 68.44 & 61.69 \\
\hline JBP-03 & 35.87 & 10.55 & 62.51 & 64.21 \\
\hline JBP-04 & 45.76 & 14.24 & 64.57 & 58.18 \\
\hline JBP-05 & 53.48 & 16.14 & 67.37 & 70.12 \\
\hline Mean & 45.81 & 13.33 & 63.54 & 63.86 \\
\hline SEO-01 & 19.39 & 6.12 & 55.35 & 65.86 \\
\hline SEO-02 & 41.88 & 13.96 & 67.39 & 53.69 \\
\hline SEO-03 & 43.37 & 11.83 & 71.25 & 70.87 \\
\hline SEO-04 & 16.95 & 5.98 & 66.08 & 42.13 \\
\hline SEO-05 & 23.01 & 8.00 & 39.19 & 65.04 \\
\hline Mean & 28.92 & 9.18 & 59.85 & 59.52 \\
\hline DHR-01 & 42.15 & 13.05 & 60.08 & 62.79 \\
\hline DHR-02 & 36.54 & 10.15 & 70.23 & 65.31 \\
\hline DHR-03 & 20.33 & 7.11 & 69.02 & 49.41 \\
\hline DHR-04 & 23.14 & 9.06 & 64.44 & 68.31 \\
\hline DHR-05 & 25.92 & 11.40 & 48.27 & 65.24 \\
\hline S.Em \pm & 2.21 & 0.89 & 2.53 & 9.63 \\
\hline C.D.5\% & 6.33 & 2.53 & 7.24 & \\
\hline level & & & & \\
\hline & & & & \\
\hline & & & & \\
\hline
\end{tabular}


Table.4 Qualitative performance of custard fruit of various landraces

\begin{tabular}{|c|c|c|c|c|c|c|}
\hline Genotypes & $\begin{array}{c}\text { TSS } \\
\left({ }^{0} \mathrm{Brix}\right)\end{array}$ & $\begin{array}{c}\text { Acidi } \\
\text { ty } \\
(\%)\end{array}$ & $\begin{array}{c}\text { Total } \\
\text { sugar } \\
(\%)\end{array}$ & $\begin{array}{l}\text { Reducing } \\
\text { sugar }(\%)\end{array}$ & $\begin{array}{c}\text { Non reducing } \\
\text { sugar }(\%)\end{array}$ & $\begin{array}{c}\text { TSS: } \\
\text { acidity } \\
\text { ratio }\end{array}$ \\
\hline СHH-01 & 19.81 & 0.74 & 18.05 & 13.33 & 4.72 & 26.71 \\
\hline СНH-02 & 26.83 & 0.56 & 18.90 & 14.89 & 4.01 & 47.92 \\
\hline CHH-03 & 30.49 & 0.22 & 23.76 & 16.79 & 6.97 & 141.67 \\
\hline СHH-04 & 25.48 & 0.53 & 17.38 & 15.35 & 2.03 & 48.07 \\
\hline CHH-05 & 26.99 & 0.45 & 19.11 & 15.51 & 3.60 & 60.41 \\
\hline JBP-01 & 24.99 & 0.71 & 17.38 & 14.61 & 2.77 & 35.02 \\
\hline JBP-02 & 12.99 & 1.18 & 14.90 & 13.30 & 1.60 & 11.01 \\
\hline JBP-03 & 19.21 & 0.89 & 17.57 & 14.51 & 3.06 & 21.67 \\
\hline JBP-04 & 27.68 & 0.46 & 20.59 & 14.57 & 6.02 & 60.24 \\
\hline JBP-05 & 25.53 & 0.59 & 19.72 & 13.57 & 6.15 & 43.50 \\
\hline SEO-01 & 29.72 & 0.36 & 22.88 & 16.84 & 6.04 & 83.33 \\
\hline SEO-02 & 27.93 & 0.44 & 20.59 & 14.77 & 5.82 & 63.48 \\
\hline SEO-03 & 23.69 & 0.62 & 21.80 & 13.21 & 8.60 & 38.36 \\
\hline SEO-04 & 27.03 & 0.54 & 21.47 & 15.70 & 5.77 & 50.36 \\
\hline SEO-05 & 30.15 & 0.35 & 22.45 & 15.85 & 6.60 & 85.73 \\
\hline DHR-01 & 22.10 & 0.87 & 18.49 & 14.38 & 4.11 & 25.51 \\
\hline DHR-02 & 24.82 & 0.67 & 19.84 & 13.96 & 5.89 & 37.05 \\
\hline DHR-03 & 28.76 & 0.49 & 21.09 & 16.06 & 5.03 & 59.24 \\
\hline DHR-04 & 26.62 & 0.57 & 20.93 & 14.74 & 6.19 & 46.41 \\
\hline DHR-05 & 30.19 & 0.35 & 24.08 & 18.15 & 5.94 & 86.25 \\
\hline S.Em \pm & 1.36 & 0.04 & 0.71 & 0.43 & 0.50 & 4.36 \\
\hline $\begin{array}{c}\text { C.D.5\% } \\
\text { level }\end{array}$ & 3.89 & 0.11 & 2.02 & 1.23 & 1.42 & 12.48 \\
\hline
\end{tabular}

While Kymore plateau and Satapura hill zone i.e. Jabalpur recorded the lowest average value of $22.08{ }^{\circ} \mathrm{Brix}$ and ranges from 12.94 to 27.68 0Brix. Thus critically it was noted that genotype belongs to Chhindwara, Seoni and Dhar possessed the higher content of TSS i.e. $30.49,30.15$ and $30.19{ }^{0}$ Brix was recorded with JBP - 02 which was significantly lowest over all the genotypes collected under study.

The variation in TSS in 30 genotypes collected globally was reported by Kumar et al., (2018). However the ranges between genotypes were narrow. As regards to the acidity percentage it was noted that there is a reciprocal relationship with the TSS.
The highest TSS recorded the lowest acidity percent in almost all the zones. The lowest percentages of acidity (22\%) were recorded with $\mathrm{CHH}-03$ which was significantly lowest over all the other group of genotypes.

The highest acidity percentage of $1.18 \%$ was recoded under JBP -02 which have the lowest (12.99 ${ }^{0}$ Brix)TSS. Recorded the ratio of TSS and acidity was maximum under $\mathrm{CHH}-03$ (1.18) while minimum (0.11) was noted with JBP -02 . The similar trend in variability in terms of acidity was recorded in genotypes of GC -7 and GC -13 collected from Gujarat by Yadav et al., (2017). 
The maximum total sugar was recorded in DHR-05(24.08) followed by CHH-03(23.7), SEO-01(22.88) and SEO-05(22.45)and minimum was under JBP-02(14.90).

Whereas the maximum reducing sugar $18.15 \%$ was observed in DHR-05 which showed significantly superior over all the genotypes.

Minimum reducing sugar ( $13.21 \%$ ) was recorded in SEO-03. These results are in agreement with Othman et al., ( 2014) and Nagar et al., (2017).

The maximum non-reducing sugar was observed in SEO-03 (8.60\%) followed by CHH-03 (6.97\%) and SEO-05 (6.60\%) as compared to other genotypes, while, it was observed minimum under JBP-02(1.60\%). Pandey et al., 2016 also reported the variation in physical parameters (yield attributes) and chemical parameters (quality) and standerd that it was due to the inherent genetic makeup of the genotypes, which is some way influenced the morphological characters and expression expressed through the activity of endogenous growth regulators.

From the above findings it could be concluded that there was a significant variation in morphological characters, fruit yield and quality characters of custard apple genotypes.

The genetype SEO-04 was found most promising genotype among the 20 accessions for maximum length $(90.55 \mathrm{~mm})$, width (91.49 $\mathrm{mm})$, weight (287.77 $\mathrm{g}$ ), fruit pulp per cent $(71.25 \%)$ and non-reducing sugar per cent $(8.60 \%)$. Genotypes SEO-04 was also noted minimum number of seeds fruit $^{-1}$ (16.95), weight of seeds fruit ${ }^{-1}(5.98 \mathrm{~g})$ and peel weight fruit ${ }^{-1}(42.13 \mathrm{~g})$.

Landraces DRH -04 exhibited maximum volume of fruit (266.65 cc), TSS (30.49), acidity per cent $(0.22 \%)$ and TSS: acidity ratio (141.67) was registered maximum in $\mathrm{CHH}-03$. Landraces DHR-05 was noted maximum total sugar per cent $(24.08 \%)$ and reducing sugar per cent $(18.15 \%)$. This genotype can be used for table as well for processing purposes.

\section{References}

A.O.A.C. ( 1995). Official Methods of Analysis $16^{\text {th }}$ Ed, Virginia,: 838-841.

Anonymous (2017). Horticulture statistics at a glance 2017.Published by Department of Agriculture, Cooperation and Farmers Walfare, Ministry of Agriculture and Farmers Walfare, Govt. of India.pp. 15.

Bhatnagar, Prerak, Singh, Jitendra, Jain, M. C. and Singh, Bhim(2012).Evaluation of landraces of custard apple (Annona squamosa L.).Plant Archives. 12 (2): 1045-1048.

Diwan, Kamlesh; Naik, D. M.; Vadak, Yogesh; Anil S. Taruand Maholiya, Bantesh Kumar (2014).Variability, correlation and path analysis studies for superior types of sweet orange (Citrus sinensis Osbeck). International Journal of Agricultural Sciences. 10 (2): 649-653.

Gopalan C., Ramashastri, B. V. and Balasubramaniam, S. C. ( 1987). Nutritive value of Indian foods. National Institute of Nutrition, Indian Council of Medical Research, Hyderabad, India, pp 1-204.

Hashmi, Syed Imran and Pawar, V. N. (2012). Studies on physical and chemical characteristics of custard apple fruit pulp from different locations. $J$. Dairying, Foods \& H.S. 31 (2): 117 120.

Kad, V. P., Jadhav, M. S. and Nimbalkar, C. A. ( 2016).Studies on physical, morphological and rheological properties of custard apple (Annona 
squamosal L). International Journal of Applied and Pure Science and Agriculture (IJAPSA).02 (04): 140147.

Kolekar, T. N. and Tagad, V. B. (2012).Studies on physico-chemical properties of custard apple fruit.Indian Streams Research Journal. 2 (8): 1-4.

Kumar Y, Chandra A K, Dubey, A and Gajera H P. ( 2018) Fruit morphology and quality parameter studies of global custard apple (Annona squamosa) Germplasm. Int.J. curri. MicrobialAppl.Sci. 7(10): 1297-1311.

Lizana, L. A. and Reginato, G. ( 1990). "Cherimoya" In: Fruits of Tropical and Subtropical Origin: Composition, Properties and Uses.Edited by Nagy S.; Shaw, P. E. and Wardowski, W. F.; Florida Science Source, Lake Alfred, Florida, USA. pp. 131-148.

Nagar, Pawan K., Satodiya, B. N., Haresh L. Dhaduk and Prajapati, D. G. (2017).Genetic variability and biochemical screening of guava (Psidium guajava L.) hybrids.International Journal of Chemical Studies. 5 (6): 143-146.

Nair, R and Agrawal V (2017), A review on the nutritional quality and medicinal value of custard apple. An under utilized crop of Madhya Pradesh,
India.Int.J.Curr. Microbial. App. Sci.6(8): 1126-1132.

Othman, Chande Othman, Christina, Fabian and Esther, Lugwisha(2014). Post harvest physicochemical properties of soursop (Annona muricataL.) fruits of Coast region, Tanzania. Journal of Food and Nutrition Sciences.2 (5): 220-226.

Pandey,D., Pandey, A.K. and Yadav, S.K. (2016) Evaluation of newly developed guava cultivar and section under Lucknow conditions. Indian J. Hort., 73:334-338.

Pinto, A. C. de Q., Cordeiro, M. C. R. and Andrade, S. R. M. de. ( 2005). A monograph on Annona species.International centre for underutilised crops, University of Southampton, UK.

Raina, Dimpy; Dhillon, W. S. and Gill, P. P. S. (2014).Genetic variation, heritability and correlation analysis of forty seven pear genotypes under subtropics. Journal of Applied Horticulture. 16 (2): 146-148.

Yadav, V. Singh A K, Singh S and Appa Rao, VV(2017) Variability in custard apple (Annona squamosa L.) genotypes for quality characters from Gujarat. Int. J. Agril.Sci. 87(12):1627-1632.

\section{How to cite this article:}

Kamleshwar Goutam, T. R. Sharma, B. K. Verma, U. K. Chanderia and Pandey, S. K. 2019. Genetic Variability in Custard Apple Landraces of Madhya Pradesh, India. Int.J.Curr.Microbiol.App.Sci. 8(10): 2201-2209. doi: https://doi.org/10.20546/ijcmas.2019.810.256 